\title{
CONTEXTUAL TEACHING AND LEARNING METHOD TO IN TEACHING READING AT THIRD YEAR STUDENTS OF MTSN BALANG-BALANG GOWA REGENCY
}

\author{
Nurbaeti Halik \\ Madrasah Tsanawiyah Negeri Balang-Balang \\ Tyas.ahdan@yahoo.com
}

\begin{abstract}
The objectives of this research were to find out (1) whether or not contextual teaching and learning method improve the reading achievement of the third year students of MTsN Balang-Balang (2) whether or not the students are motivated in learning English reading using contextual teaching and learning method.This research applied quasi experimental design. The subject of the research was the third year students of MTsN Balang-Balang Kabupaten Gowa. The data collected were the students' reading achievement through test and the students' motivation of experimental group through quetionnaires. The data from the test and the questionnaire were analyzed quantitatively. The result of the data analysis showed that the mean score of the experimental group was higher than the control group in reading achievement.it is 68.92. The mean score of motivation of the experimental group was 79.9. It means that the students were motivated of Contextual Teaching and learning method. Based on the findings, the writer concluded that the use of Contextual Teaching and Learning Method was effective to increase the reading achivement of the third year students of MTsN BalangBalang.
\end{abstract}

Keywords: Contextual Teaching and Learning Method, the reading achievement

\section{A. INTRODUCTION}

$\mathrm{E}$

nglish is very important to be learned by the students. There are four skills that must be mastered in learning English, they are Listening, Speaking, Reading and

Writing.Reading is one of the skills which has to be learned by students who are studying language and considered as the most important skill. Nunan (1999:66) says that reading is the most important skill to be mastered in order to ensure. According to him, success is not only in learning English but also in learning any contents class were reading in English is required. However, reading is a complex activity deploying a large number of separate actions. One should use the understanding and imagination, observing, and remembering. He cannot read without moving the eyes or using his minds. Comprehension and reading speed become very dependent on proficiency in performing all the necessary organs for it. Reading is central to the learning process, by reading activity; people may gain important information that is not presented by teachers in the classroom.

Teaching and learning process of English in Junior High School mostly emphasize on reading, writing, listening and speaking integratedly. Besides those four language skills in teaching English, vocabulary, structure, spelling etc must also be considered. Teaching English for Junior High School, especially in reading class for the third grade, conveys the 
competence of identifying ideational meaning in the text, identifying interpersonal rhetoric in the context, and reading the texts aloud. Such a process requires certain approach in teaching. The competence standard should be mastered by SMP students in reading is to understand various meaning in written texts. The competence covers interpersonal, ideational and textual meaning.

In fact, most students still have low competence in this skill. For them English is a difficult and boring lesson, so it makes the students less motivated tolearn. Teachers are often unable to encourage students to find entertaining and interesting information in reading materials. Whereas, the success of implementing reading skill depends on the students's interest.

Based on the curriculum, one of the purposes of learning reading in junior high school at the third grade is to develop the ability to communicate in English verbally or written, so the students are able to read the written text correctly. Generally some schools do not easily achieve the goal of learning reading in accordance with what are stated in the curriculum. Moreover in the writer's school where most of the students speak Makassar as their mother tongue in the classroom, the other factors are limited facilities. As we know that the use of available facilities optimally help the students understand the material being taught.

In relation to the result of National Examination at Yunior high school, especially in MTsN Balang-Balang, it was proved that English competence of the students were in a low level. The average was 4.05 .

The problem they experienced in English is concerning with reading competence. Most students are lack in English. It is shown from their passing grade in English that are below of minimum passing grade required by the curriculum as a more intensive observation undertaken; the problem is mostly in reading comprehension. Students are unable to comprehend the reading materials in the text. Therefore their understanding on material taught is quite poor.

Based on the fact above, it is necessary for language teachers to foster reading on their students. It may be done by selecting proper materials to the students. Teachers should select reading materials that are relevant to the students's needs and interests. Teacher should also select methods that are fun for the students, because selecting the wrong method will hinder the achievement of learning objectives. Bahari (1991:16) says that "Teacher will not be able to do his task if he does not master any method of teaching which has been formulated by the psychologist and education scientist". According to him, there are a lot of methods in teaching language such as, discussion, role playing, number head together, story mapping and discovery, but sometimes the teacher doesn't think whether it matches to learning goals, so it makes the method useless.

In this research the writer focuses on the using of contextual teaching and learning method in teaching reading. Johnson (2002:25) states that "Contextual teaching and learning 
is an educational process that aims to help students see meaning in the academic material they are studying by connecting academic subjects with the context of their daily lives, that is, with context of their personal, social, and cultural circumstance. To achieve this aim, the system encompasses the following components: making meaning full connections, doing significant work, self-regulated learning, and collaborating, critical and creative thinking, nurturing the individual, reaching high standards and using authentic assessment".

According to Johnson (2002:24), CTL is a learning method, which consists of the following eight important elements. They are making meaningful connection, doing significant work, self regulates learning, collaborating, critical thinking, nurturing the individual, reaching high standards and using authentic assessments.

One of the interesting elements is collaborating. Collaboration removes the mental blinders imposed by limited experienced and narrow perceptions. It makes it possible to discover personal strengths and weaknesses to learn to respect others, listen with an open mind, and build consensus. In working together, the members of small groups are able to overcome obstacles, actindependently and responsibly, rely on the talents of team members, trust others, speak up, and make decisions (Johnson, 2002: 89).

Based on the backround of the study,the writer will formulate research questions as follows:

1. Can teaching reading using contextual teaching and learning method improve the reading achievement of the third year students of MTsN Balang-Balang?

2. Are the students motivated in learning English reading using contextual teaching and learning method?

\section{B. BASIC THEORY}

\section{Reading}

\section{a. Definition of Reading}

Reading is the activity between the reader and the writer's idea, where the writer sends his idea in the written symbols and then the reader catching the idea in it. Reading is very complex to learn and to teach. As Harmer (1991:190) states, "Reading is an exercise dominated by the eyes and the brain." The eyes receive messages and the brain then has to work out the significance of these messages. Brown (1994:283) says, "Reading ability will best be developed in association with written, listening, and speaking activity."

Reading is actually a conversation of shorts between a writer and a reader. Clark and Silberstein in Simanjuntak (1988:15) defines reading is an active cognitive process, of interacting with printing and monitoring comprehension to establish meaning. Reading is the instantaneous recognition of various written symbols with existing knowledge, and comprehension of the information and ideas communicated. 
Clark and Silberstein in Ariani (2002) outlined implication of the perspective of native - language reading for the preparation and use of second language reading materials as follow: (1) reading is seen as an active process. The reader forms preliminary expectations about the material then selects the fewest, more productive cues necessary to confirm or to rejects those expectations. (2) Reading must be viewed as two fold phenomenon involving process (comprehending) and product (comprehension). The process of working through reading task, including the mistakes and false starts this entails, is often as important in learning to read as is the production of correct responses to post facto comprehension questions.(3) reading involves an interaction between thought and language. The reader brings to the task a formidable array of information and ideas, attitudes, and beliefs.

\section{b. Principles of Reading}

Harmer (1991:190) states that reading is an exercise dominated by the eyes and the brain. The eyes receive message and the brain then has to work out the significance of the messages. A reading text moves at the speed of the reader or other words it is up the reader to decide how fast he/she wants to read the text.

When we read, we may deal of language, Harmer (1991:142) says that the basic principles of reading are on the content, purpose and expectation and receptive skills. This can make the goal of the reading can be achieved as well as the teaching reading can be successfully developed the students' in learning. Therefore, the reading actively can develop the student's capability.

For many learners, beginning to read the language involves learning an entire new set of written symbols, Ur (1996:141). Therefore, the teachers need to make the guidelines to begin the reading. The natures of the tasks that the teachers plan to set and whether the teachers require students to attempt, such tasks before, during or after have studied the text. 1) Pre- reading tasks

Such tasks enable students to familiarize themselves with the content of a text. Activities can be systematic such as vocabulary exercises or schematic, such as thinking of the purpose of a text or predicting the content from its title).

2) While- reading tasks

Those kinds of task, as Hedge (2000) in Woods (2005:65) states, they become used: since the adoption of the idea reading as an interactive process. These encourage learners to be active as they read. The students given activities that require them to do any of the following: follow the order of ideas in a text; react to the opinion expressed; understand the information it contains; ask themselves questions; make notes; confirm expectations of prior knowledge or predict the next part of a text from various clues.

3) Post-reading tasks

These tasks follow up the work covered and seek to extend candidates. Such activities 
are directed writing activities, or role-play and group discussion activities.

\section{c. Levels of Reading Comprehension.}

Fairbairn and Winch (1996:14) divides the level of comprehension into three categories:

1. Literal comprehension

It is getting the primary, direct, literal meaning of an idea in context. There is no depth in this kind of reading. The reader is reading receptively and somewhat passively if only gets literal meaning. Being able to read for literal meaning stated idea is influenced by one's mastery of vocabulary in context. Billerica (2005:2) stated that in the literal comprehension, the answer is clearly stated all in one place, in one sentence or two sentences together in the reading passage. There may be clue words. Students can find the answer clearly in one place in the passage text. So, some questions that can be asked to students in this level are finding vocabulary in context, recalling details and understanding sequence.

\section{Interpretative comprehension}

In this level of comprehension the reader read between the lines make connection among individual stated ideas. Make inference, draw conclusion, or experience emotional reaction. The readers probe for greaterdepth than in literal comprehension. Billerica (2005:2) explains that in interpretative comprehension students can get answer in the text, but it is not located all in one place. And there probably aren't clue words. Students find pieces of information that they can put together to answer the questions. They are concerned with supplying meanings not directly stated in the text. At this level the readers can be tested on the following task:

a) Rearrange the ideas or topic discussed in the text

b) Explain the author's purpose of writing in the text

c) Summarize the main idea when this is not explicitly stated in the text.

d) Select conclusion which can be defined from the text they have read.

3. Extrapolative comprehension

In this level of comprehension, the reader is involved in an interchange of ideas with the author and applies reading to life situation. The author's ideas and information are evaluated. The answer is not directly stated in the text, but it is hinted at (implied). Students use clues, along with their prior knowledge, to figure out the answer (Billerica, 2005:2). Extrapolative evaluation occurs only after the students have understood the ideas and information the writer presented. At this level, the readers can be tested on the following skills:
a. The ability to differentiate between fact and opinion
b. The ability to recognize persuasive statement
c. The ability to judge the accuracy of information in the text. 
Nurbaeti Halik, Contextual Teaching and Learning Method...

The level of reading classification of Fairbairn and Winch that is used in this research is Literal comprehension and interpretative comprehension.

\section{d. Strategies in Teaching Reading}

Brown (2000:306) mentions ten strategies of reading comprehension, each or which are practically applied to the classroom techniques.

1. Identify the purpose in reading; the efficient reading consists of clearly identifying the purpose in reading something. By doing so, we know what we are looking for and we can weed out potential distracting information.

2. Use graphemes rules and pattern to aid in bottom-up decoding; this strategy is good for beginning level learners. At the beginning levels of learning English, one of difficulties students encounter in learning to read is making the correspondence between spoken and written English. In many cases, learners have become acquainted with oral language and have some difficulty learning English spelling conventions.

3. Use efficient silent reading for relatively rapid comprehension; this strategy is good for intermediate to advanced level students because they need not to be speed readers but you can helped them to increase efficiency by teaching a few silent reading rules that include: (1) you do not need to "pronounce" each word to yourself (2) try to visually perceive more than one word at a time, preferably phrases, and (3) unless a word is absolutely crucial to global understanding, skip over it and try to infer its meaning through context.

4. Skimming; it consists of quickly running one's eyes across a whole text to get the gist. It gives readers to the advantage of being able to predict the purpose of the passage, the main topic or message, and possible some of the developing or supporting ideas.

5. Scanning; its purpose is to extract certain specific information without reading through the whole text. So, the exercise of this strategy may as students to look for names or dates, to find definition of essential concept, or to list a certain number of supporting details. In vocational or general English, scanning is important in dealing with genre like schedules, manuals, forms, etc.

6. Semantic mapping or clustering; it help the reader to provide some order to the chaos. Making such semantic maps can be done individually, but they make for a productive group work technique as students collectively induce order and hierarchy to a passage.

7. Guessing; in this strategy, learners can use guessing to their advantage to guess the meaning of the word, a grammatical relationship, a discourse relationship, a cultural reference, a content of the messages, and to infer implied meaning (between the lines).

8. Vocabulary analysis; it means that when the learners do not know immediately recognize a word in the passage, one way for them to make guessing they know is to analyze it in terms of what they know about it. 
9. Distinguish between literal and implied meaning; this require the application of sophisticated top-down processing skills. The fact that not all language can be interpreted appropriately by attending to its literal, syntactic surface structure makes special demands on readers.

10. Capitalized on discourse makers to process relationships; this strategy is good for the learners of intermediate proficiency levels. Therefore, they ought to be thoroughly familiar with the types of discourse makers.

Furthermore, Brown (2000:313) proposes 8 techniques in designing interactive reading techniques they are:

1. Make sure that you don't over look the importance of specific instruction in reading skill.

2. Use techniques that are intrinsically motivating.

3. Balance authenticity and readability in choosing texts.

4. Encourage the development of reading strategies.

5. Include both bottom-up and top-down-techniques.

6. Follow the"SQ3R" sequence (survey, question, read, recite and review).

7. Subdivide your techniques into pre-reading, during- reading, and after reading phases.

8. Build in some evaluative aspect to your techniques.

From the strategies which proposed by the experts, the writer thinks that "Using Contextual Method in Teaching Reading " can improve the students' reading comprehension.

\section{e. Teaching Reading in EFL Classes}

Reading, as one of receptive skill in learning English deals with how some one gets information from written form. Broughton,et al (2003:89) says reading is a complex skill which includes the component of recognizing the black mark, the correlation of linguistic element, and also the correlation of meaning. The most typical use of reading in a foreign language class is to teach the language itself. The underlying assumption of the notion is that reading might be used to extend one's command of language in such a case that it can provide a major avenue for development of power in using language for learning new words or new concepts.

Teaching reading in EFL class can also function to prepare students to read information and material (Dowson, 1987). The focus should be on helping students acquire the skills needed in an attempt at constructing meaning. To a ttain such a purpose, therefore, a teacher holds a role in helping students acquire the skill needed for beginning their experience to bear upon materials. Including the teacher should assist the students to use their skills of reading efficiently and effectively. A student who reads English may have 
difficulty reading foreign language. Therefore, must take account where teaching the reading skills (Edward et al., 1977).

Harmer (2000) outlines some principles that underlie the effective teaching of reading. First, reading is not a passive skill. The skill implies that the students have to understand what is read before beginning to read, such as understanding what the words mean, seeing the picture what word is conveying, understanding the arguments, and working out if they agree with them. Second, the students need to be engaged in to what they are reading. To engage the students need in reading, the teacher should provide the reading text that interests them and the topic that stimulates them as well. Third, the students should be encouraged to respond to the content of a reading text, not just to the language. This principle implies that the meaning or the message of the text is important as the way the language is used. The teachers, therefore, must give the students a chance to respond to that message in some way. Prediction is the major factor in reading as its principle meant that the students should have in mind the expectation of what they would find in reading is ready to begin. Fourth, the task should be matched to the topic. This principle underlies that teachers need to choose and decide good reading task for which students are going to accomplish, such as the right kind of questions. Finally, the good teachers should exploit reading text to the full. This principle states that the teacher should integrate the reading text in to interesting class sequences, and using the topic for discussion and further task.

\section{f. Task Technique to Provide in Teaching Reading Skills}

The preliminary act before teaching a reading in class, the teachers need to select activities available in textbooks or design their own for a class they are teaching. Ur (1996) states that a task is useful for two reasons: (1) it may provide the students with a purpose in reading and make the whole activity more interesting and effective; (2) the teachers need to know how well their students are reading, and they can get this information conveniently through looking at the results of comprehension task.

In giving the students task from the textbooks to stimulate reading, it does not always do so effectively. The task is usually also followed by comprehension questions. It is, however, setting question to answer - before or after reading - not only one way to get the students comprehend the text. There may be a lot of activities do not base on comprehension questions. They are for example; the teachers give the students a set of title together with a set of extracts from different newspaper articles or stories and ask them to match the tittles to the appropriate extraction.

To stimulate students' thinking and their reading, some possible activities may give to them as what Ur (1996) proposes as follows:

1. Pre - question. A general question is given before reading, asking the students to find out a piece of information central to the understanding of the text;

2. Do - it yourself question. Students compose and answer their own questions; 
3. Provide a title. Students suggest a title if none was given originally; or alternative, if there was one;

4. Summarize. Students summarize the content in a sentence or two. This may also be done in the first language;

5. Continue. The text is a story; students suggest what may happen next;

6. Gap the text. Towards the end of the text, four or five gaps are left that can only be filled in if the text that has been understand;

7. Look for mistakes. The text has occasional mistake (wrong words or intrusive ones; or mission). Students are told in advance how many mistakes to look for;

8. Compare. There are two texts on a similar topic; students note points of similarity or difference of content;

9. Respond. The text is a letter or a simple provocative text; students discuss how they would respond, or write an answer;

10. Re - present of content. The text gives information or tell a story; students re-present its content through a different graphic medium, such as a drawing that illustrates the text, making a map, list of events or items described in the text and diagram ( such as a flowchart) indicating relationship between items, events or character.

11. Respond of content. This is like in the re-presentation of content. The text gives information or tell a story; students respond its content through a different graphic medium, such as a drawing that illustrates the text, marking up, list of events or items described in the text and diagram (such as flowchart) indicating relationship between items, events or character.

\section{Contextual Teaching and Learning}

a. The Understanding of CTL

According to Sanjaya (2009:225) the philosophy of CTL was rooted from progressivisms of John Dewey. John Dewey, an expert of classical education proposed the theory of curriculum and teaching methodology related to the student's experience and interest. Principally, the students will learn effectively if they can make a connection between what they are learning with the experience they had, in other word the students have background knowledge related to the topic, and also they actively involved in learning process in the classroom. John Dewey, as quoted by Donald (1999:34) states that what an individual has learned in the way of knowledge and skills in one situation becomes an instrument of understanding and dealing effectively with the situation which follows. The process goes on as long as life and learning continue.

The word 'contextual' naturally replaced 'applied' academics because the word 'applied' was simply too small to encompass the startling innovations achieved by this grassroots reform movement. The more comprehensive contextual in context implies the interrelatedness of all things. Everything is connected including ideas and actions. Contextual 
Nurbaeti Halik, Contextual Teaching and Learning Method...

also directs our thinking toward experience. When ideas are experienced, in context, they have meaning.

The theory of Cognitive also influenced the philosophy of CTL. The students will leam so well if they actively involved in the classroom activities and have a chance to inquire it by themselves. Students will show their learning achievement through the real things that they can do. Learning is regarded as an effort or intellectual activity for developing their idea through introspection activity (Wina, 1999:255).

Based on two theories above, the CTL philosophy was developed. CTL is a proven concept that incorporates much of the most recent research in cognitive science. It is also a reaction to the essentially behaviorist theory that have dominated American education for many decades. CTL is promoted as the alternative for the new learning strategy. CTL emphasizes the learning process through constructing not memorizing and teaching is interpreted as an activity of inquiring process not only transferring knowledge to the students. In CTL, students are expected to develop their own understanding from their past experience or knowledge (assimilation). It is important because our brain or human mind functioned as the instrument for interpreting knowledge so that it will have a unique sense.

Meanwhile, several attempts have been made to define the meaning of CTL method. In the process of searching the meaning of CTL, the writer has found several definitions about it from different resources. Johnson (2002:25) divines CTL as follows:

CTL is an educational process that aims to help student see meaning in the academic subject with the context of their daily lives, that is, with the context of their personal, social, and cultural circumstances. To achieve this aim, the system encompasses the following eight components: making meaningful connections, doing significant work, self-regulated learning, and collaborating, critical and creative thinking, nurturing the individual, reaching high standards, and using authentic assessments.

In addition, Bern and Erickson (2011:4) states that

Contextual teaching and learning is a conception of teaching and learning that helps teachers relate subject matter content to real world situations and motivates students to make connections between knowledge and its applications to their lives as family members, citizens, and workers and engage in the hard work that learning requires.

Meanwhile, the Washington State Consortium for Contextual Teaching and Learning in Wina (2009:225) formulates the definition of CTL as Follow:

Contextual teaching is teaching that enables students to reinforce, expand, and apply their academicknowledge and skills in a variety of in school and out-of school settings in order to solve the stimulated or real world problem. 


\section{RESEARCH METHOD}

In this research, the writer applied quasi experimental design; the non equivalent control group designs (Gay, 2006:258). It used two groups, one group receiveved treatment (Contextual teaching and learning method) and the other group received non Contextual Teaching and Learning Method). Both groups were given pretest and posttest. The pretest was done to find out the prior knowledge of students while posttest was done to find out the effectiveness of teaching reading by using Contextual Teaching and Learning Method. The design formulated as follow:

\begin{tabular}{cccc} 
EG & $\mathrm{O}_{1}$ & $\mathrm{X}_{1}$ & $\mathrm{O}_{2}$ \\
\hline CG & $\mathrm{O}_{1}$ & $\mathrm{X}_{2}$ & $\mathrm{O}_{2}$
\end{tabular}

Figure 1 Research design (adapted from Gay, 2006:258)

Where:

$\mathrm{EG}=$ Experimental Group

$\mathrm{O}_{1}=$ Pre test

$\mathrm{X}_{1}=$ Ttreatment with contextual Teaching and learning approach

$\mathrm{X}_{2}=$ Treatment with non ccontextual Teaching and learning Approach

CG $=$ Control Group

$\mathrm{O}_{2}=$ Post test

\section{Population and Sample}

The population in this research was the third year students of MTsN Balang Balang kab Gowa academic year 2013/2014 which consisted of five classes. Each classess consisted of 36 students so the total population were 175 students. The sample was selected based on purposive sampling technique. The writer chose two classes, $\mathrm{IX}_{4}$ as a control group and $1 \mathrm{X}_{3}$ as an experimental group.

Purposive means that the writer had a purpose to choose class $\mathrm{IX}_{3}$ and class $\mathrm{IX}_{4}$, based on the students' achievement on English subject in semester test, the test given was reading test and the result of the test class $\mathrm{IX}_{1}$ and $\mathrm{IX}_{2}$ achieved higher than students of other classes. While the students of $\mathrm{IX}_{3}$ and $\mathrm{IX}_{4}$ achieved lower mean score. The students of the classes had nearly the same ability level. The following are the data which shows the third grade students' score of the semester test for English.

Table 1 : Result of Students' Mean Score of Mid Semester for Reading

\begin{tabular}{|c|c|c|}
\hline NO & CLASS & MEAN SCORE \\
\hline 1 & $\mathrm{IX}_{1}$ & 67 \\
\hline 2 & $\mathrm{IX}_{2}$ & 60 \\
\hline 3 & $\mathrm{IX}_{3}$ & 56 \\
\hline 4 & $\mathrm{IX}_{4}$ & 58 \\
\hline 5 & $\mathrm{IX}_{5}$ & 65 \\
\hline & TOTAL MEAN SCORE & 61,2 \\
\hline
\end{tabular}

Source: English Teacher Assessment's book 
Nurbaeti Halik, Contextual Teaching and Learning Method...

\section{Research Instrument}

The writer employed two kinds of instrument, they are as test and questionnaire.

\section{FINDINGS}

The findings that the writer reports in this chapter are based on the data analysis collected by using tests, they are pretest and posttest for experimental and control group.

\section{Students' Reading Comprehension Achievement in Pretest and Posttest}

Having conducted the treatment, the writer found the score for pretest and posttest of both groups on the students' reading comprehension achievement results. In this part, the writer reports the result of both groups by comparing the pretest and posttest of both groups.

a. Students' reading comprehension achievement

1) Scoring classification of students' pretest of experimental and control group

Before the experiment was conducted by the writer, both experimental group and control group were given pretest in order to know the prior knowledge of the students' reading achievement. Furthermore, the purpose of the test was to find out whether both experimental and control group were at same lavel or not and posttest was given after the experiment to find out whether the students' reading achievement increase or not

In this classification, the writer shows the frequency and percentage of students' pretest of experimental group and control group.

Table 1. Frequency and percentage of students' reading comprehension in pretest

\begin{tabular}{|c|l|c|c|c|c|}
\hline \multirow{2}{*}{$\begin{array}{c}\text { Range of } \\
\text { Score }\end{array}$} & \multirow{2}{*}{ Clasification } & \multicolumn{2}{|c|}{ Experimental Group } & \multicolumn{2}{c|}{ Control Group } \\
\cline { 3 - 6 } & & $\mathbf{F}$ & $\mathbf{\%}$ & $\mathbf{F}$ & $\mathbf{\%}$ \\
\hline $81-100$ & Very Good & 0 & 0 & 0 & 0 \\
\hline $61-80$ & Good & 2 & 5.6 & 3 & 8.3 \\
\hline $41-60$ & Fair & 20 & 55.6 & 20 & 55.6 \\
\hline $21-40$ & Poor & 14 & 38.8 & 11 & 30.5 \\
\hline$>21$ & Very Poor & 0 & 0 & 2 & 5.6 \\
\hline & & $\mathbf{3 6}$ & $\mathbf{1 0 0}$ & $\mathbf{3 6}$ & $\mathbf{1 0 0}$ \\
\hline
\end{tabular}

Table 1 shows that most of students that most students in experimental and control group were in fair category. The frequency of experimental categorized good was 2 students (5.6\%), fair 20 students (55.6\%) and poor was 14 students (38.8\%), while in control group, the sum of frequency categorized good was 3 students (8.3\%), fair 20 students $(55.6 \%)$, poor was 11 students (30.6\%) and very poor was $2(5.6 \%)$. Based on the frequency of both experimental and control group showed that the students in fair category were bigger than poor category, however it signifies that both groups still need to be increased.

2) Scoring classification of students' posttest of experimental and control group

In this classification the writer shows the frequency of percentage of students' post test of experimental and control group.. 
Table 2. Frequency and percentage of the students' reading achievement in posttest

\begin{tabular}{|c|l|c|c|c|c|}
\hline \multirow{2}{*}{$\begin{array}{c}\text { Range of } \\
\text { Score }\end{array}$} & \multirow{2}{*}{ Classifications } & \multicolumn{2}{|c|}{ Experimental Group } & \multicolumn{2}{c|}{ Control Group } \\
\cline { 3 - 6 } & & $\mathbf{F}$ & $\mathbf{0}$ & $\mathbf{F}$ & $\mathbf{0}$ \\
\hline $81-100$ & Very Good & 2 & 5.6 & 0 & 0 \\
\hline $61-80$ & Good & 27 & 75 & 10 & 27.8 \\
\hline $41-60$ & Fair & 7 & 19.4 & 15 & 41.7 \\
\hline $21-40$ & Poor & 0 & 0 & 10 & 27.8 \\
\hline$>21$ & Very Poor & 0 & 0 & 1 & 2.8 \\
\hline \multicolumn{2}{|r|}{} & $\mathbf{3 6}$ & $\mathbf{1 0 0}$ & $\mathbf{3 6}$ & $\mathbf{1 0 0}$ \\
\hline
\end{tabular}

Table 2 shows that the students' achievement in experimental and control group got increase after the experiment. The percentage of the students' reading achievement both of the group generally tend to spread in ve good category. The frequency of experimental group in very good category was 2 students (5.6\%), good category was 27 students (75\%), fair category was 7 students (19.4\%) and none of students in poor category, while in control group, none of students in very good category, 10 students $(27.8 \%)$ was in good category, fair category was 15 students (41.7\%), poor was 10 students $(27.8 \%)$ and very poor was 1 students $(2.8 \%)$.

The distribution of the score of the students' reading achievement for experimental and control group in posttest shows the difference from the pretest. After conducting the experiment, both of the groups showed an increase but in experimental group was higher than control group.

Table 3 Mean Score and Standard Deviation of the Students' Reading Comprehension Achievement in Pretest and Posttest.

\begin{tabular}{|l|l|c|c|}
\hline & \multicolumn{1}{|c|}{ Group } & Mean & Standard Deviation \\
\hline Pretest & Experimental Group & 44.22 & 12.15 \\
\hline & Control Group & 44.67 & 12.93 \\
\hline Posttest & Experimental Group & 68.92 & 9.08 \\
\hline & Control Group & 51.33 & 16.53 \\
\hline
\end{tabular}

Table 3 shows the difference of mean score and standard deviation in pretest and posttest to the both of the groups. The data was based on the computation by using SPSS 17.0.

The data from from the table 4.2 shows that the mean score of experimental group and control group was mostly in the same score before giving the treatment.Afterconducting the experimenting, the score of the posttest of experimental and control group showed the difference score of mean score. It means that there was an increase after conducting a treatment. The table 4.3 shows that the mean score of the students' pretest of experimental group was 44.22 and standard deviation was 12.15 , while in control group, the mean score of the students' pretest was 44.67 and standard deviation was 12.93 . The mean score of both groups were different after the experimenting was conducted. The mean score of the students' posttest of the experimental group after the treatment was 68.92 with standard 
deviation 9.08, while the mean score of the students' posttest of the control group was 51.33 with standard deviation was 16.536, it means that the mean score of experimental group is higher than control group $(68.50>51.33)$.

b. Test of Significance (T-Test)

The hypotheses were tested by using inferential analysis. In this case, the writer used t-test (testing of significance) for independent sample test. That is a test to know the significance betqween the result of students'mean scores in pretest and posttest for experimental and control group.

Assuming the level of significance $(\alpha)=0.05$, the only thing which is needed, the degree of freedom $(\mathrm{df})=70$, where $\mathrm{N} 1+\mathrm{N} 2-2=70$; than the result of the t-test is presented in the following table:

Table .4. Probability Value T- Test of the students'Reading Comprehension Achievement in Experimental and Control Group

\begin{tabular}{|l|c|c|l|}
\hline \multicolumn{1}{|c|}{ Variable } & P - Value & $(\boldsymbol{\alpha})$ & \multicolumn{1}{|c|}{ Remarks } \\
\hline $\begin{array}{l}\text { Pretest of experimental and } \\
\text { control group }\end{array}$ & 0.867 & 0.00 & Not significantly different \\
\hline Posttest of experimental & 0.00 & 0.00 & Significantly different \\
\hline
\end{tabular}

Based on the result of data analysis as summarized in the table 4 on pretest of experimental and control group, the writer found that the probability value $(0.867)$ is higher than the level of significance at the t-table $(0.00)$ and the degree of freedom 70 . It menas that $\mathrm{H}_{0}$ was accepted and $\mathrm{H}_{1}$ was rejected. In other words, there was no significant difference between students reading comprehension achievement both groups, experimental and control group before the experimenting. It is supported by Gay (2006:124) states that when variables have equal interval, it is assumed that the difference between close score is essentially the same.

While the data on posttest of control and experimental group showed that the probability value was smaller than $\alpha(0.00<0.05)$. It indicated that the alternative hypothesis $\left(\mathrm{H}_{1}\right)$ was accepted and the null hypothesis $\left(\mathrm{H}_{0}\right)$ was rejected. It means that the application of Contextual Teaching and Learning Method increases the students' reading comprehension achievement.

This means that the data of posttest as the final result gave significant increase. It was concluded that the use of contextual teaching and learning method was able to give contribution in teaching English especially in teaching reading. Nevertheless the achievement could be more enhanced when the application of CTL method is given in a more expandable time rather than 6 consecutive meeting.

\section{Students' Motivation}

The questionnaire was distributed to the students to know their motivation toward contextual teaching and learning method in teaching reading at the third year students of 
MtsN Balang-Balang Kabupaten Gowa. The Students' score interval of questionnaire was described in the following tables.

Table 5. Frequency and Percentage of the students' Motivation toward Contextual Teaching and learning Method in Teaching Reading

\begin{tabular}{|c|l|c|c|}
\hline \multirow{2}{*}{ Interval Score } & \multicolumn{1}{|c|}{ Categori } & \multicolumn{2}{c|}{ FC CTL in Teaching Reading } \\
\cline { 3 - 4 } & & $\mathbf{F}$ & $\mathbf{0}$ \\
\hline $85-100$ & Strongly motivated & 10 & 27.8 \\
\hline $69-84$ & Motivated & 23 & 63.9 \\
\hline $52-68$ & Moderate & 3 & 8.3 \\
\hline $36-51$ & Unmotivated & - & - \\
\hline $20-35$ & Strongly Unmotivated & - & - \\
\hline \multicolumn{2}{|l}{ Total } & $\mathbf{3 6}$ & $\mathbf{1 0 0}$ \\
\hline
\end{tabular}

The data of the students' interval score based on the questionnaire on the table 5 magnifies that the use of contextual teaching and learning method shows that 10 students' $(28 \%)$ felt strongly motivated, 23 students (64\%) felt motivated, and only 3 students (8\%) felt neutral which is categorized as moderate motivated, and none of students felt unmotivated and strongly unmotivated.

Table 6. Mean Score of the Students' Motivation

\begin{tabular}{|c|c|c|}
\hline Group & Mean & Standeviation \\
\hline Contextual Teaching and Learning Method & 79.9 & 8.00 \\
\hline
\end{tabular}

The table 6 shows that the mean score of contextual teaching and learning method was 79.9 which categorized as motivated class. It means that the students motivated toward the use of contextual teaching and learning method in teaching reading.

\section{E. Discussion}

The discussion deals with arguments and further interpretation of the research findings through test and questionnaire.

\section{Students' Reading Achievement}

In this section, the discussion deals with the techniques applied in teaching reading comprehension. The application of contextual teaching and learning method which emphasizes of learning community in teaching reading comprehension at the third year students of MTsN Balang-Balang Kabupaten Gowa can improve the students' achievement.

As Wehrh (2003:4) says the advantages of implementing learning community are the students actively involved and stimulate peer group learning or small group and it helps participants explore pre-existing knowledge and build on what they know.In applied learning community the writer gave different materials for groups. The writer saw the students who work in a group have the opportunities to ask some questions without feeling shy in other words the students had confidence to present or retell what they had learned in front of the class. 
In addition, questioning used by the teacher to check the students' understanding to encourage students's response and to know what the students have known make the students feel confident to express their answer. Morever modelling by the teacher improve the students performance, by seeing how the teacher ask their friends and how their friends answer to the teacher's questions, the other studentswould like to imitate them. It is related to previous finding by Regan (2012), which found that modelling was particularly important when teaching reading to the student.

Based on the findings above, the comparison of the improvement of students' score of the experimental and control group can be proved by analyzing the posttest result. The result shows that the mean score of the students' posttest in both groups increased after giving the treatment. It can be observed through the mean score of the both in pre-test and post-test. The students of the experimental group got $44.22 \%$ for the pre-test and $68.92 \%$ for the post-test. The score increased around $24.75 \%$ while the students, pretest for the control group got $44.67 \%$ become $51.33 \%$. This score increased around $6.66 \%$ from pre-test to posttest. It could be stated that the score of the two groups got progress, but experimental class was higher than the control group.

After analyzing the result of the data, the researcher found out that there was a significant difference between the experimental group and control group. It can be seen on the sig $=0.00<0.05$. It indicates that the alternative hypothesis $\left(\mathrm{H}_{1}\right)$ was accepted and of course, the null hypothesis $\left(\mathrm{H}_{0}\right)$ was rejected. It means that the use of Contextual Teaching and Learning Method in teaching reading significantly affected the students' reading comprehension. It was concluded, then that the use of CTL was able to give a greater contribution in teaching and learning process especially for reading class. The students showed their enthusiastic in doing this treatment. Bilash (2011) states a daily activity in every classroom is asking and answering of questions. This activity has many purposes in teaching and learning process in the class, such as to engage the students in the lesson actively, to create interest in the topic, and to develop the student's critical thinking. Asking and answering questions is one part of CTL principle. In this activity the students got a lot of chances to ask and answer the questions from their friends.

\section{The students' Motivation}

The result of the research showed that the students were motivated in learning English especially on the reading class by using Contextual teaching and learning method. During the treatment, the students were actively involved in the class sharing and giving information. They did it in pair and groups. Concerning the last activity the students should answer the questions individually. Noticing the findings and discussion above, it indicates that the use of CTL activities could increase the students' reading comprehension achievement and they were motivated in learning English, particularly in reading class. 


\section{Facts During the Research}

There are some facts happened during the treatment, as follow:

a. We can see in this research that experimental increased their reading comprehension achievement after the treatment. The writer assumed that it could be influenced by many factors such as (1) the students feel enjoyable in learning activities (2) the method that the teacher used during the treatment.

b. Another fact the writer found there were many students in experimental group got low motivation in learning English before given the treatment, but during the treatment applied most of students motivated in learning English. Harmer (1991:52) says that there are some factors which may affect motivation. They are: 1 . Physical conditions where in this part the teacher should create a pleasant classroom as possible. 2. Method, the teacher should used method which can improve the students' motivation. In this part the writer assumed that in applying CTL method the teacher should consider with students' condition. 3. Teacher, Teacher's personality may have effect on students' motivation. Therefore, a teacher needs to do everything possible to create a good rapport with the students. 4 . Success, It will be the teacher's job to set goals and tasks which most of his/her students can achieve. Success plays a vital part in the motivation of a students.

\section{F. Conclusion}

Based on the findings and discussion in the previous chapter, the writer comes to conclusions. They are as follows:

1. The use of Contextual teaching and learning Method to the third years students of MTsN Balang-Balang improved the students' reading comprehension achievement. It is proved by the mean score of the students' posttest in experimental group is higher than control group. It can be seen from the students' mean score of posttest was 68.92 for experimental group, while for control group the students's mean score of posttest was 51.33, and T-Test of the students' reading comprehension achievement in experimental and control group in posttest is smaller than $\alpha(0.00<0.05)$.

2. The use of Contextual Teaching and Learning Method increase the students' motivation in learning English especially in attending and joining the reading class. The students are motivated in learning English through the use of CTL method. It refers to the mean score of the students' motivation was 79.9 which is ctegorized high motivation. So the conclusion is the students are motivated in learning reading by using Contextual Teaching and Learning Method. 
Nurbaeti Halik, Contextual Teaching and Learning Method...

\section{REFERENCES}

Abbot, G,J. Greenwood, D, Mckeating and P. Wingard. 1985. The teaching of english as an international language: a Practicel Guide. Great Britian Biddles ltd: Guilford, survey.

Aminah. 2010. Using Pair Work. Activities in Teaching Reading to the Tenth Grade Students of SMA Negeri 1 Walenrang. Makassar: PPs UNM.

Ariani, F. 2002. Using Grammar ranslation method to increase reading comrehension of the second year students of SLTPN 13 makassar. Makassar: PPs UNM.

Bilash, Lenka. 1999. Answering and Asking Questions. IDEA Paper.

http://honolulu.hawaii.edu/intranet/committees/FacDevCom/guidebk/teachtip/as kquest.htm. Retrieved 31 Macrh 2014.

Billerica, North. 2005. Building Levels of Comprehension: Multiple Choice and Short Response Reading Questions. New Jersey: Curriculum Associates, Inc.

Betty P, Smith. 2006. Action Guide for School Nutrition and Phsyical Activity. Department of Career and Information Studies: The University of Georgia.

Broughton, Geoffrey. 2003. Teaching English as a Foreign Language. Taylor \& French e- library. Brown H, Douglas. 1994. Principles of Language Leaming and Teaching. Englewood Cliffs, New Jersey: Prentice Hall.

Brown H, Douglas. 2000. Teaching by Principle: An Interactive Approach to Language Pedagogy. San Francisco, Longman.

Charles, Clemente. 2009. CTL for Practitioners. California Colleges: A Faculty Primer Academic Senate.

Depdiknas. 2004. StandarKompetensi Mata Pelajaran Bahasa Inggris Sekolah Menengah Pertama dan Madrasah Tsanawiyah. Jakarta: Pusat Kurikulum Balitbang Depdiknas.

Depdiknas. 2006. Petunjuk Pelaksanaan Proses Belajar Mengajar dan Petunjuk Pelaksanaan Sistem Penilaian. Jakarta: BSNP.

Donald, Freeman.1999. Changing Teaching: Insight into Individual Development in the Contexts of School. A New Insights for the Language Teacher. Singapore: SEAMEO Regional Language Center.

Dowson, M.A. 1997. Fundamental Basic Reading Instruction. New York: Longman, Green and Co,Inc.

Edward, David Allen \& Rebecca M. Valette. 1977. Classroom Techniques: Foreign Language and English as a Second Language. Harcourt Brace Jovannovich. Inc.

Eggen, Paul \& Don Kauchak. 1997. Educational Psychology: Windows on Classroom. New Jersey: Prentice Hall.

Johnson, E.B. 2012. Contextual Teaching and Learning: What It Is and Why It is Here to Stay. Thousand Oaks Corwin Press, Inc. 
Elisssa Kaye, Polley. 2007. Implication for Condition in Second Language Acquisition. University of Texas.

Mulyasa, E. 2009. Kurikulum Tingkat Satuan Pendidikan. Bandung: PT. Remaja Rosdakarya.

Fairbairn, Gavin J \&Winch C. 1996. Reading, Writing and Reasoning: A guide for Students. London: Biddles Limited, Guilford \& Kings Lynn, Inc.

Fernandes, Susana. 2012. Motivation and Second Language Acquisition. Facultad De Letrays Y D La Education, Universidad De La Rioja: Grado Estudios Ingleses (601 G).

Gay, L.R, ET, al. 2006. An Educational Research: Competencies for Analysis and Application. The Eight Edition. Columbus Ohio: Charles E, Merril Publishing.

Gardner, R.C. 1985. Social Psychology and Secong Language Learning: The Role of Attitudes and Motivation. London: Edward Arnold.

Hamra, Arifuddin and Syatriana Eny. 2010. Developing a Model of Teaching Reading Comprehension for EFL Student. TEFLIN.

Harmer, Jeremy. 1991. The Practice of English Language Teaching (New Edition). New York: Longman.

Hedge, T. 2000. Teaching and Learning in The Language Classroom. London: Oxpord University Press.

Hidayani. 2008. Improving the Students'Reading Comprehension of the Second Class of SMP Negeri 15 Makassar Through SQ3R Technique. Makassar: Graduate Program State University of Makassar.

Kawaza, Samuel. 2013. Big Class Size Challenges: Teaching Reading in Primary Classes in Kampala. Uganda's Central Municipality: U.S - China Education Review A. ISSN 161-624 x David Publishing.

Naiman, N Froelic. 1978. The Good language learner. Toronto: Ontario institute for studies education.

Nunan. 1999. Second Language Teaching and Learning. Boston: Henley Publisher.

Mustamir. 2009. Teching Reading Comprehension Through Cooperative Learning to The First Year Students of SMA Negeri 2 Sinjai. Makassar: UNM.

Permen Diknas Nomor 22. 2006. Standar Kompetensi dan Kompetensi dasar bahasa Inngris. Departemen pendidikan Nasional.

Rasyid, Muhammad Amin. 1998. Kesepakatan Prinsip Pengajaran Bahasa Inggris dengan Kebijakan yang Menentukan Proses Belajar Mengajarnya: Sebuah Paradigma Pengajaran Bahasa Inggris yang Sukses. Pidato Pengukuhan Jabatan Guru Besar pada FPBS IKIP Ujung Pandang: IKIP

Regan, Kelly. 2012. Effective Reading and Writing Instructions. A Focus on Modeling. Journals@sagepub.com; Web site: http://sagepub.com.p 272-286. Retrieved 4 July 2014. 
Nurbaeti Halik, Contextual Teaching and Learning Method...

Syaiful Bahri, Djamarah. 2005. Guru dan Anak Didik dalam Interaksi Edukatif. Jakarta: PT. Rineka Cipta.

Sanjaya, Wina. 2009. Strategi Pembelajaran Berorientasi Standar ProsesPendidikan. Jakarta: Kencana Media Group.

Suhartini, Waode Threes. 2010. Improving Reading Comprehension of the Second Grade Students of SMA Negeri 5 Bau-Bau Through Directed Activities to the Text (D ARTS) Strategy. Makassar. Graduate Program State University of Makassar.

Simanjuntak B, Andi Pasaribu. 1988. Didaktik and Metodik. Jakarta: Rica Cipta.

Vaidun, Kurnia. 2012. Using Contextualized Authentic Materials in Teaching Reading Comprehension at SMP 2 Pasangkayu. Makassar: Graduate Program State University of Makassar.

Otto, W. 1979. How to Teach Reading. California: Addison weskey Publishing.

Ur, Penny. 1996. A Course in Language Teaching; Practice and Theory. United Kingdom: Cambridge University Press.

Wehrli, G and Nyuquits. Jc. 2003. Teaching Strategies and Methodologies. http.hsc.Unm.edu/som/ted/Teaching pdf. Retrieved 20 November 2013.

Wijarwadi, Wandi. 2008. The Effetiveness of Teaching Speaking Using Contextual Teaching and Learning Approach of the First Year Students of SMAN 1 Ciputat. Jakarta: Department of English Education Syarif Hidayatullah Islamic University Jaka rta.

Winter, Linda. 2004. Contextual Teaching and Learning for Science in Elementary Schools. Journal of Elementary Science Education. Vol. 16.no.2.College of Education a Human Service, Western Illinois University. Retrieved 4 July 2014.

Woods, Caroline. 2005. Teaching and Assessing Skill in Foreign languages. German: Cambridge University Press. 